\title{
(2) \\ Aguaruna Knowledge of Bird Foraging Ecology: A comparison with scientific data
}

\author{
Kevin Jernigan and Nico Dauphiné
}

\section{Research}

\begin{abstract}
We present a detailed look at local ecological knowledge (LEK) of the Aguaruna-Jívaro on plants foraged by frugivorous tropical birds. When asked how a particular plant is useful to people, Aguaruna men often mentioned whether the plant in question was eaten by birds or other animals. The Aguaruna use their knowledge about what plants particular birds eat to help them locate species when hunting. We focus on indigenous knowledge of the diet of five mainly frugivorous bird families that are of local economic importance: Cracidae (guans, chachalacas and curassows), Pipridae (manakins), Psittacidae (parrots), Ramphastidae (toucans) and Steatornithidae (Oilbird). Fieldwork took place in communities along tributaries of the upper Marañón river in the Peruvian Amazon from 2003 to 2005. Results indicate a high correspondence between western science and Aguaruna LEK. This research contributes to the larger goal of promoting dialog between indigenous and scientific systems of knowledge in the context of future conservation efforts.
\end{abstract}

\section{Introduction}

Indigenous people sometimes harbor knowledge that supersedes scientific knowledge, such as the case of the Bedouin in Syria who demonstrated that a bird species thought extinct by scientists did in fact still persist in the wild (Serra 2003). During the last decade researchers in several fields have shown increasing interest in local ecological knowledge (LEK) that indigenous and other groups of people have of plant-animal interactions, animal behavior and plant communities (Fleck \& Harder 2000, Gilmore 2005, Nabhan 2000, Posey 1979, Posey 1981, Shepard et al. 2001). To date, however, there has been little research on indigenous knowledge specifically about ecological relationships between birds and plants. Gilchrist et al. (2005) present a compelling case for scrutinizing LEK with the purpose of applying it to wildlife management de- cisions, while Gilchrist \& Mallory (2007) note that "tangible examples of [LEK's] application to wildlife management are rare."

We present a detailed look at LEK of members of a native Amazonian group, the Aguaruna-Jívaro, regarding plants foraged by frugivorous tropical birds. We then compare their LEK with relevant scientific knowledge to assess the level of correspondence between these two bodies of knowledge. We will focus here on this question as it applies to five mainly frugivorous families of birds: Cracidae (guans, chachalacas and curassows), Ramphastidae (toucans), Psittacidae (parrots), Steatornithidae (Oilbird) and Pipridae (manakins). These families are important to the Aguaruna, either in terms of their usefulness or their prominence in folklore. For each of these five families, we discuss Aguaruna folk classification of the species found in the area, as well as the information provided by our informants on food plants composing the diet of each bird family. We then provide a more detailed account of Aguaruna LEK about bird diet as compared with available scientific data for one focal species per family.

\section{Correspondence}

Kevin Jernigan, Ethnobotany Program, Kuskokwim Campus, University of Alaska, Bethel, AK 99559. U.S.A.

awatidiam@yahoo.com

Nico Dauphiné, Warnell School of Forestry and Natural Resources, University of Georgia, Athens, Georgia 30602. U.S.A.

Ethnobotany Research \& Applications 6:093-106 (2008) 
Other than some limited ornithological (e.g., Berlin et al. 1981, Boster et al. 1986) and botanical research (e.g., Berlin 1970, Lewis et al. 1999), little scientific exploration has taken place in the region of northern Peru occupied by the Aguaruna. Diet, ecology and basic natural history of many bird species in the region remain poorly known (del Hoyo et al. 1994, Parker et al. 1996). The Aguaruna as a group have demonstrated extensive familiarity with the bird species found in their environment (Berlin \& Berlin 1983, Berlin et al. 1981, Boster et al. 1986). A high degree of correspondence has been shown between Aguaruna folk taxonomy and scientific classification for both birds (Berlin et al. 1981, Boster et al. 1986) and plants (Berlin 1970, 1992).

\section{Methods}

We conducted research between 2003 and 2005 in several indigenous Aguaruna-Jívaro communities along Upper Marañón and Nieva rivers in the northern Peruvian Amazon (Figure 1). We carried out structured interviews about birds and plants with 10 Aguaruna informants: four in the community of Kayamas and six in the community of Wichim. We asked the informants to make a list of birds they could name (hereafter freelist), and then asked them which of those birds were kumpají (companions) to es- tablish which birds they considered to be related. We then asked the informants to describe the diet for each bird on their freelist. When an informant mentioned that a particular species foraged on fruits, we requested that he give specific plant names. We also obtained some basic data on preferred foraging stratum and habitat for each species by asking informants whether the bird was 'ground dwelling' or 'canopy dwelling,' and whether the bird was pakajíya (lowland) or mujajíya (montane).

We used data from our field observation of birds to establish correspondence between the folk genera mentioned and species as designated by scientific taxonomy. We also drew on data from the investigations of Berlin et al. (1981) and Boster et al. (1986) on the Cenepa River, and those of Guallart (1969) at various sites. In most cases, data from these three sources are in agreement, but we have noted some differences that may reflect regional or temporal variation in naming. We made botanical collections in the vicinity of our research sites to determine most of the plant names mentioned by informants when describing bird diet. Voucher specimens of these collections were deposited at the herbarium of the Universidad Nacional Mayor de San Marcos (UNMSM) in Lima. We also supplemented our taxonomic data with data collected by Berlin (1970) and Guallart (1997).

Figure 1. Map of the study area in the northern Peruvian Amazon.

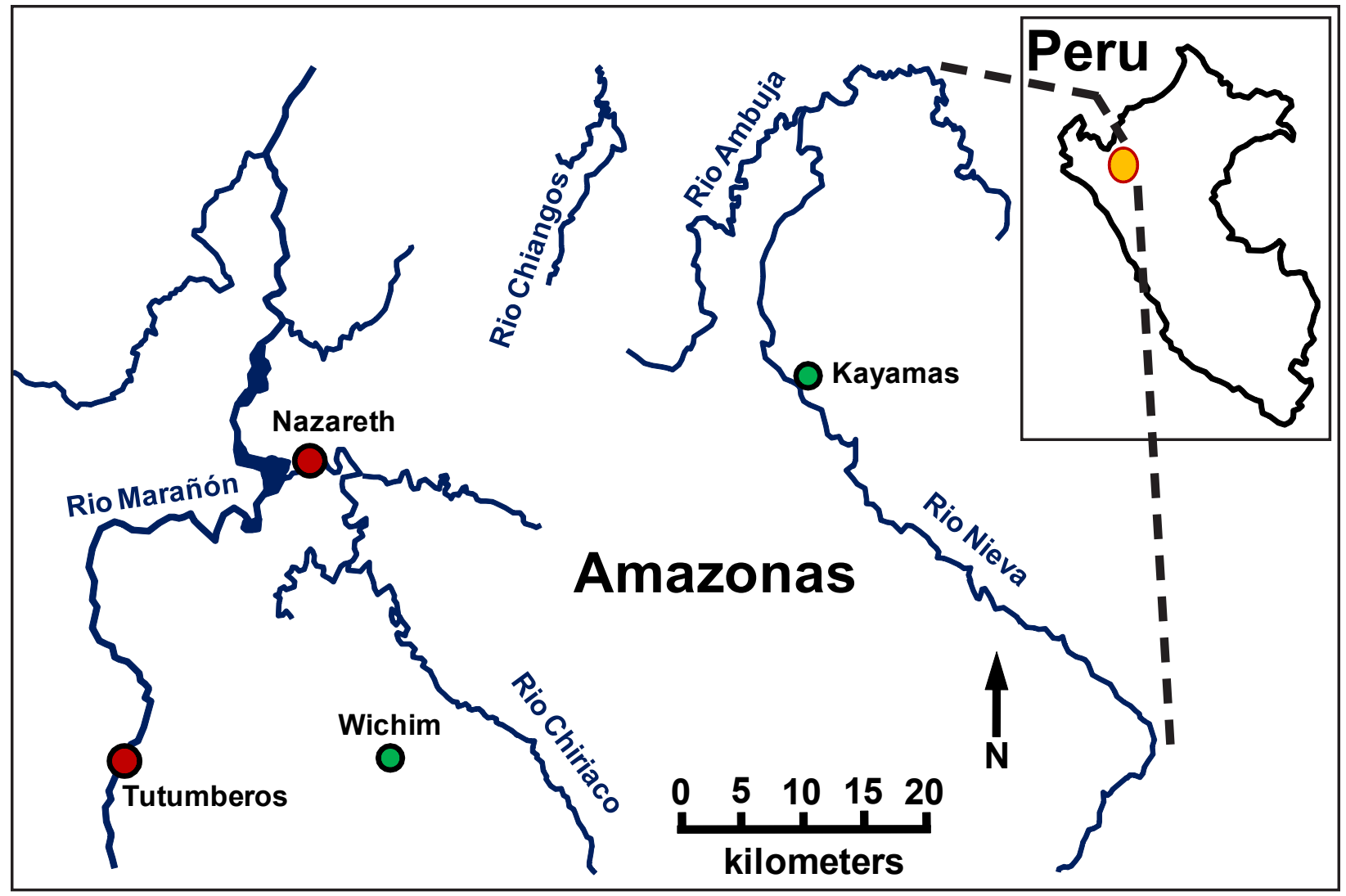




\section{Jernigan \& Dauphiné - Aguaruna Knowledge of Bird Foraging Ecology: A comparison with scientific data}

We chose five bird species for the comparison of LEK of bird diet with corresponding scientific data: the Wattled Guan Aburria aburri, the Channel-billed Toucan Ramphastos vitellinus, the Blue-headed Parrot Pionus menstruus, the Oilbird Steatornis caripensis and the Golden-headed Manakin Pipra erythrocephala. For these species, we compared plants named as food for the birds by Aguaruna informants to available corresponding scientific data. We compare the data sets mostly at the broad level of plant families because some of the scientific studies were conducted in locations such as Trinidad or the Brazilian Atlantic forest that were far from our own study site, and so not all of the same species or even genera can be expected to occur in such widely separated locations. In addition, a few Aguaruna plant terms that informants mentioned are very broad and correspond more or less to an entire botanical family. For example, the term tínchi corresponds to the family Lauraceae and the term chinchák corresponds to the family Melastomataceae.

\section{Results and Discussion}

We recorded a total of 249 Aguaruna bird folk genera, of which 127 are considered partially or fully frugivorous, and observed 126 species corresponding to reported folk genera in the field. Some Aguaruna bird folk genera correspond fairly well to scientific genera; for example, the Aguaruna genus pinínch is equivalent to the scientific genus Pteroglossus (araçaris). Some folk genera correspond to a single species; for example, achayáp is the Golden-headed Manakin $P$. erythrocephala. Other folk genera may correspond to entire avian families; the word jémpe, for instance, is a general term for hummingbirds. Our complete list of Aguaruna bird names show that about $90 \%$ of folk genera are monotypic while the remaining $10 \%$ have two or more folk species.

The Aguaruna give linguistic recognition to only a few intermediate level taxa (Berlin 1992) within the life form píshak. For example, the Aguaruna term yámpits refers to doves (family Columbidae) and pínchu to hawks (order Falconiformes). However, informants readily recognize the relatedness of many avian families and say that the members are kumpají (companions) or patají - 'family' (Jernigan 2006). For example, informants said that wága (Tinamus major), sékuch (Tinamus osgoodi) and wagkúsh (Crypturellus sp.), which all correspond to birds in the family Tinamidae, are companions. The Aguaruna language does not have a single general word equivalent to the English word 'tinamou' but has words for various kinds of tinamou. The Aguaruna make a distinction between nugkáya píshak (ground dwelling birds) and yakíya píshak (canopy dwelling birds).

\section{Cracidae: Curassows, Guans and Chachalacas}

The family Cracidae includes the largely arboreal chachalacas, guans and piping guans and the terrestrial curassows (Brooks 2006). The Aguaruna give linguistic recognition to more than half a dozen folk genera of birds in the Cracidae. These include: the guans aúnts (Penelope jacquacu), kúyu (Aburria cumanensis), pítsa (Chamaepetes goudotii) and uwáchau ( $A$. aburri); and the curassows báshu (Mitu sp.), píwi (Crax globulosa) and ayáchui (Nothocrax urumutum). The genus báshu includes the folk species múun báshu, which corresponds to the Razor-billed Curassow Mitu tuberosa. Berlin \& O'Neill (n.d.) identify wakáts as Ortalis guttata while Guallart (1969) lists it as Penelope montagnii. Some Aguaruna believe that all of the birds in this family are related as companions, but there are many who separate the curassows from the other cracids. The Aguaruna highly value cracids as gamebirds. Brown (1984) names the cracid species báshu (Mitu sp.), kúyu (Aburria cumanensis), aúnts ( $P$. jacquacu) and wakáts ( $P$. montagnii) as particularly favored game species of the Aguaruna in the Alto Mayo region. In our study area, informants reported that some cracid species, particularly múun báshu (Razor-billed Curassow) and píwi (Wattled Curassow) are no longer present; thus these may have been recently extirpated from the areas where we worked.

Cracids are predominantly frugivorous (Clements \& Shany 2001, Hilty \& Brown 1986, Ridgely \& Greenfield 2001). Members of this family feed mainly on fruits, seeds and tender shoots but they also eat arthropods, mollusks and tree frogs. Curassows tend to forage on fruits fallen on the ground or from low branches although the Wattled Curassow is more arboreal than others in this group; guans and chachalacas tend to feed mostly in the middle and upper canopy (del Hoyo 1994). The Aguaruna consider birds of this family to consume mainly fruits and seeds. One informant said that ayáchui ( $N$. urumutum) and aúnts $(P$. jacquacu) also eat námpich, a general term for worms. Aguaruna informants stated that curassows are typically ground dwelling birds while guans and chachalacas are generally placed as canopy dwelling birds. There was a slight disagreement on this point for certain species however; one informant said that pítsa (C. goudotii) and aúnts ( $P$. jacquacu) are ground dwelling. Aguaruna informants most commonly listed fruits of many trees, especially species in the following families, as food sources for cracids: Araliaceae (genus Schefflera), Burseraceae (genus Dacryodes), Lauraceae, Melastomataceae, Meliaceae, Moraceae, Myristicaceae and Rubiaceae (genus Isertia).

The Wattled Guan ( $A$. aburri) has a range extending from northern Colombia to southern Peru, inhabiting primary and late secondary montane forest. Its conservation status is near threatened due to habitat loss and hunting pressure (IUCN 2006). In Peru, it is normally found at elevation between1000-1900 m above sea level (a.s.I.), 
but it has also been observed at $500 \mathrm{~m}$ (del Hoyo 1994). Wichim and Kayamas are located at $400 \mathrm{~m}$ and $290 \mathrm{~m}$ a.s.I. respectively, but both communities are located near mountains at elevation greater than $1000 \mathrm{~m}$ a.s.I. It is likely that the Aguaruna in our study region do not generally observe the Wattled Guan except on hunting trips to nearby higher elevation areas.

Ríos et al. (2005) recently published data on the principal plant species comprising the diet of the Wattled Guan, based on a study conducted in the Columbian Andes at 1800-2100 m a.s.I. In Table 1, we compare plants mentioned in Ríos et al. (2005) with Aguaruna LEK as provided by our Aguaruna informants. Four out of ten (40\%) of the plant families that Aguaruna informants mentioned also appear in Ríos et al. (2005). Table 1 shows our Aguaruna data and the ornithological data collected by Ríos et al. (2005). Data from Ríos et al. (2005) appears under the heading 'Ornithological Data'. The section labeled 'Aguaruna Data' contains plant names that informants commonly named as food for the species in question, along with botanical determinations of those names. The table is organized so that plant families in each data set match up for easy comparison.

\section{Psittacidae: Parrots}

The family Psittacidae includes parrots, parakeets and macaws. The Aguaruna recognize more than a dozen folk genera within this family. These include the macaws wácha (Ara severus), takúm (Ara ararauna), yúsa (Ara macao) and shaámak, which our informants identified as Orthopsittaca manilata and Guallart (1969) lists as Ara militaris. The Aguaruna recognize the parrots tuwísh (P. menstruus), chawáit (Pionus chalcopterus), kawáu (Amazona sp.), uwájmas (Amazona ochrocephala) and

Table 1. Diet data for Uwáchau (Wattled Guan Aburria aburri).

\begin{tabular}{|c|c|c|}
\hline \multirow{2}{*}{$\begin{array}{l}\text { ORNITHOLOGICAL DATA }{ }^{1} \\
\text { (SCIENTIFIC NAME) }\end{array}$} & \multicolumn{2}{|c|}{ AGUARUNA DATA } \\
\hline & SCIENTIFIC NAME & AGUARUNA NAME \\
\hline \multicolumn{3}{|l|}{ Araliaceae } \\
\hline Dendropanax macrophyllus Cuatrec. & Schefflera sp. ${ }^{2}$ & séntuch \\
\hline \multicolumn{3}{|l|}{ Burseraceae } \\
\hline$\longrightarrow$ & Dacryodes sp. & újuts \\
\hline \multicolumn{3}{|l|}{ Fabaceae } \\
\hline- & Inga sp. & sámpi \\
\hline \multicolumn{3}{|l|}{ Lauraceae } \\
\hline Ocotea oblonga (Meisn.) Mez & $\begin{array}{l}\text { Ocotea floribunda (Sw.) Mez } \\
\text { Ocotea cf. wachenheimii Benoist }{ }^{2}\end{array}$ & batút \\
\hline Aniba muca (Ruiz \& Pav.) Mez & $\begin{array}{l}\text { Licaria sp. } \\
\text { Ocotea costulata (Nees) Mez }\end{array}$ & káikua \\
\hline$\longrightarrow$ & $\begin{array}{l}\text { Ocotea argyrophylla Ducke } \\
\text { Ocotea longifolia Kunth }\end{array}$ & tuntúu tínchi \\
\hline \multicolumn{3}{|l|}{ Melastomataceae } \\
\hline$\longrightarrow$ & Bellucia cf. pentamera Naudin & sáu chinchák \\
\hline- & Miconia poeppigii Triana ${ }^{2}$ & yujúya \\
\hline \multicolumn{3}{|l|}{ Moraceae } \\
\hline- & Ficus sp. & yapít \\
\hline \multicolumn{3}{|l|}{ Myristicaceae } \\
\hline$\longrightarrow$ & Virola sp. & takáikit tsémpu \\
\hline \multicolumn{3}{|l|}{ Myrsinaceae } \\
\hline Geissanthus francoae Pipoly & $\longrightarrow$ & - \\
\hline \multicolumn{3}{|l|}{ Olacaceae } \\
\hline- & Minquartia guianensis Aubl. & páini \\
\hline
\end{tabular}


Jernigan \& Dauphiné - Aguaruna Knowledge of Bird Foraging Ecology: A comparison with scientific data

\begin{tabular}{|c|c|c|}
\hline \multirow{2}{*}{$\begin{array}{l}\text { ORNITHOLOGICAL DATA }{ }^{1} \\
\text { (SCIENTIFIC NAME) }\end{array}$} & \multicolumn{2}{|l|}{ AGUARUNA DATA } \\
\hline & SCIENTIFIC NAME & AGUARUNA NAME \\
\hline \multicolumn{3}{|l|}{ Rubiaceae } \\
\hline Guettarda crispiflora Vahl & Coussarea brevicaulis K. Krause & supínim \\
\hline \multicolumn{3}{|l|}{ Symplocaceae } \\
\hline Symplocos quindiuensis Brand & - & - \\
\hline \multicolumn{3}{|l|}{ Urticaceae } \\
\hline- & Coussapoa sp. $^{2}$ & kasúa \\
\hline Cecropia telealba Cuatrec. & Pseudolmedia laevis (Ruiz \& Pav.) J.F. Macbr. ${ }^{2}$ & chími \\
\hline
\end{tabular}

${ }^{1}$ Ríos et al. 2005

${ }^{2}$ from ethnobotanical collections of Berlin et al. n.d.

tigkú (Amazona amazonica); the parakeets pajái (Aratinga mitrata), chípi (Aratinga leucophthalma) and mantseét (Pyrrhura picta) and the parrotlets kíjus (Brotogeris jugularis) and shiwíg (Forpus xanthopterygius). Our informants identified nuinúi as Touit strictoptera, while Berlin \& O'Neill (n.d.) reported Brotogeris cyanoptera for that name. Some informants consider all members of the family Psittacidae to be related as kumpají, while others divide them up into two groups. One informant put the macaws (wácha, takúm, yúsa and shaámak) into a sepa-

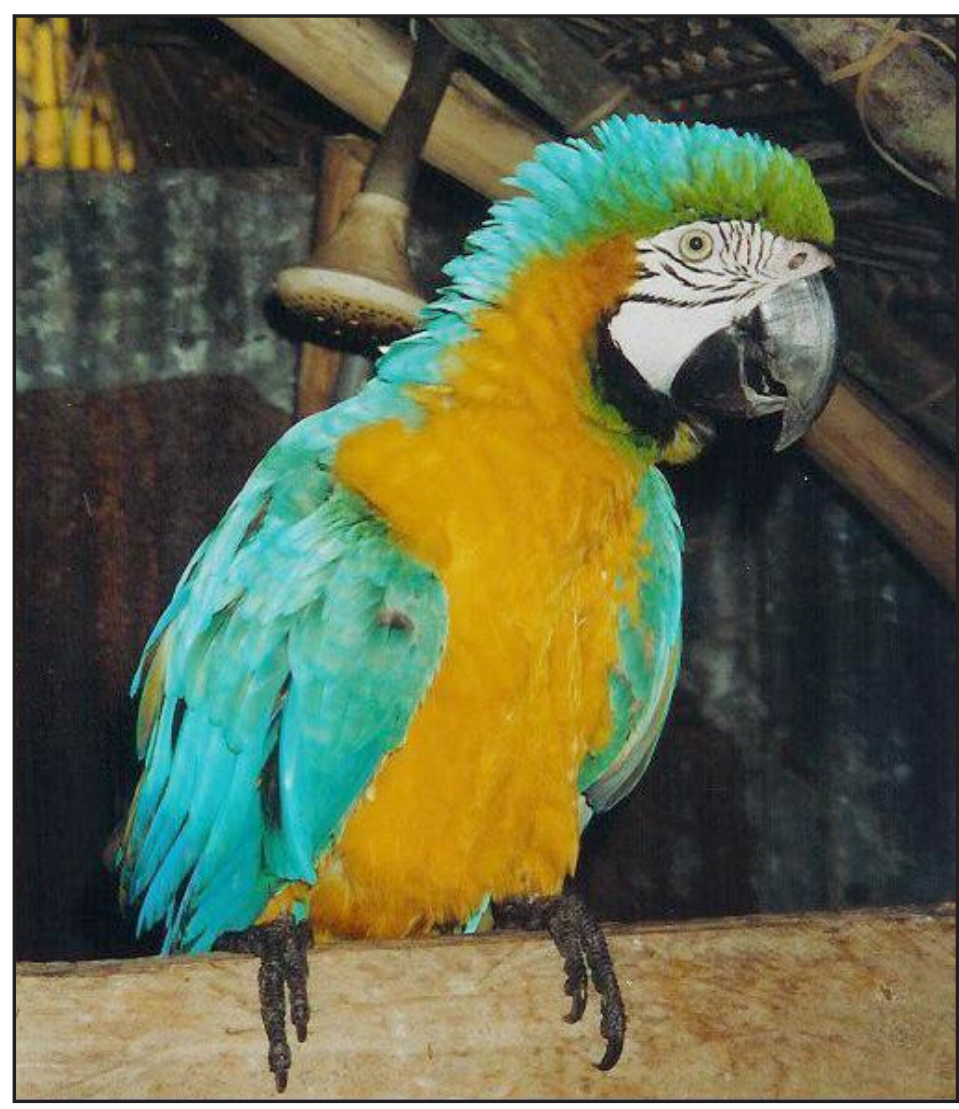

Figure 2. A Takúm (Blue-and-gold Macaw Ara ararauna) in the care of the Reátegui family, Santa María de Nieva. rate group; another informant divided the parrots into two groups based on tail length, with the macaws and other long tailed parrots in one group, and short tailed parrots, such as those in the genera Pionus, Brotogeris and Forpus, in the other group. The Aguaruna may consume birds in this family and occasionally keep them as pets (Figure 2). Members of the family Psittacidae eat mostly tree fruits and seeds, often foraging high in the canopy. Some species have very strong beaks capable of cracking hard shells (Sick 1993). Aguaruna informants named many tree species whose fruits or flowers are foraged by Psittacids. Informants said that the macaws mainly eat the fruit of the Fabaceae (genus Inga), Euphorbiaceae (genera Aparisthmium, Hevea, Hura); and Lecythidaceae (genus Eschweilera) For the parrots, parakeets and parrotlets, informants most commonly mentioned the fruit of the Burseraceae (genus Dacryodes), Fabaceae (genus Inga), Lauraceae and Moraceae (genus Pseudolmedia). Informants also said that many macaws and other parrots consume the fruit and flowers of Erythrina sp. (Fabaceae).

Tuwísh (the Blue-headed Parrot) ranges from Costa Rica in the north to Bolivia in the south and Brazil in the east. The species is common in lowland humid forest and gallery forest up to an elevation of $1400 \mathrm{~m}$ a.s.I. Collar (1997) has compiled diet data from a variety of sources for the Blue-headed Parrot. The data is presented only to the level of genus (Table 2). Six out of the nine $(67 \%)$ families mentioned by Aguaruna informants appeared in Collar (1997), who mentions eight additional families not named by Aguaruna informants.

\section{Steatornithidae: Oilbird}

The family Steatornithidae has a single member, the Oilbird (S. caripensis), which is known to the Aguaruna as táyu. A few informants 
Table 2. Diet data for Tuwísh (Blue-headed Parrot Pionus menstruus)

\begin{tabular}{|c|c|c|}
\hline \multirow{2}{*}{$\begin{array}{l}\text { ORNITHOLOGICAL DATA }{ }^{1} \\
\text { (SCIENTIFIC NAME) }\end{array}$} & \multicolumn{2}{|c|}{ AGUARUNA DATA } \\
\hline & SCIENTIFIC NAME & AGUARUNA NAME \\
\hline \multicolumn{3}{|l|}{ Anacardiaceae } \\
\hline $\begin{array}{l}\text { Anacardium sp. } \\
\text { Mangifera sp. }\end{array}$ & $\longrightarrow$ & $\longrightarrow$ \\
\hline \multicolumn{3}{|l|}{ Apocynaceae } \\
\hline - & Tabernaemontana undulata Vahl & íwakip \\
\hline \multicolumn{3}{|l|}{ Arecaceae } \\
\hline Euterpe sp. & Oenocarpus mapora H. Karst. ${ }^{2}$ & shímpi \\
\hline \multicolumn{3}{|l|}{ Burseraceae } \\
\hline Tetragastris sp. & Dacryodes nitens Cuatrec. & tsáju kunchái \\
\hline \multicolumn{3}{|l|}{ Clusiaceae } \\
\hline $\begin{array}{l}\text { Caraipa sp. } \\
\text { Clusia sp. }\end{array}$ & $\longrightarrow$ & $\longrightarrow$ \\
\hline \multicolumn{3}{|l|}{ Euphorbiaceae } \\
\hline $\begin{array}{l}\text { Hevea sp. } \\
\text { Hura sp. }\end{array}$ & Aparisthmium cordatum Baill. & dátash \\
\hline \multicolumn{3}{|l|}{ Fabaceae } \\
\hline Albizia sp. & Inga sp. & sámpi \\
\hline Dialium sp. & Inga marginata Willd. & sejempách \\
\hline Erythrina sp. & Erythrina sp. & shikiú \\
\hline Inga sp. & Pithecellobium basijugum Ducke & mujayá samíknum \\
\hline - & Inga edulis Mart. & wámpa \\
\hline \multicolumn{3}{|l|}{ Goupiaceae } \\
\hline Goupia sp. & $\longrightarrow$ & $\longrightarrow$ \\
\hline \multicolumn{3}{|l|}{ Lauraceae } \\
\hline Ocotea sp. & various species in Lauraceae & tínchi \\
\hline \multicolumn{3}{|l|}{ Marcgraviaceae } \\
\hline Norantea sp. & - & $\longrightarrow$ \\
\hline \multicolumn{3}{|l|}{ Melastomataceae } \\
\hline- & Miconia poeppigii Triana ${ }^{3}$ & yujúya \\
\hline \multicolumn{3}{|l|}{ Monimiaceae } \\
\hline - & Siparuna sp. & mejégkach \\
\hline \multicolumn{3}{|l|}{ Moraceae } \\
\hline $\begin{array}{l}\text { Ficus sp. } \\
\text { Brosimum sp. } \\
\text { Pseudolmedia sp. }\end{array}$ & Pseudolmedia laevis ${ }^{3}$ & chími \\
\hline \multicolumn{3}{|l|}{ Myrtaceae } \\
\hline Psidium sp. & - & - \\
\hline \multicolumn{3}{|l|}{ Sapotaceae } \\
\hline Micropholis sp. & - & - \\
\hline \multicolumn{3}{|l|}{ Urticaceae } \\
\hline Pourouma sp. & - & $\longrightarrow$ \\
\hline
\end{tabular}


Jernigan \& Dauphiné - Aguaruna Knowledge of Bird Foraging Ecology: A comparison with scientific data

\begin{tabular}{|l|l|l|}
\hline \multirow{2}{*}{$\begin{array}{c}\text { ORNITHOLOGICAL DATA } \\
\text { (SCIENTIFIC NAME) }\end{array}$} & \multicolumn{2}{|c|}{ AGUARUNA DATA } \\
\cline { 2 - 3 } & \multicolumn{1}{|c|}{ SCIENTIFIC NAME } & AGUARUNA NAME \\
\hline Verbenaceae & - & - \\
\hline Tectona sp. & & \\
\hline
\end{tabular}

1 del Hoyo et al. 2002

${ }^{2}$ from ethnobotanical collections of Guallart 1997

${ }^{3}$ from ethnobotanical collections of Berlin et al. n.d.

mentioned two folk species, úchi (small) táyu and múun (large) táyu. This distinction in the folk taxonomy does not appear to correspond to any recognized scientific taxonomic difference, and it is not clear how these folk species are thought to be different, other than size. The Oilbird is an economically important species for the Aguaruna. They make expeditions to caves where the birds live and harvest nestlings, which have a high percentage of body fat. Although not considered to be globally threatened, the Oilbird has been suffering dramatic population declines throughout its range with colonies near human settlements most vulnerable to extirpation (Roca 1994). In at least one Oilbird colony in our study area, most or all Oilbird nestlings present every year are reported to be harvested by local residents to the point that the continued survival of the colony appears to be in jeopardy (Dauphiné et al. in press).

Oilbirds range from Costa Rica to Bolivia in the south and northern Brazil and Guyana in the east. During the day, Oilbirds roost in caves and grottos, typically in mountainous areas, up to an elevation of $3400 \mathrm{~m}$ a.s.I. (Thomas 1999). Oilbirds forage at night in the surrounding forest and are exclusively frugivorous. They eat only the pericarp of fruits, regurgitating the seeds. They have highly developed olfactory capacities (del Hoyo et al. 1994), and tend to favor aromatic fruit, particularly those of the families Arecaceae, Burseraceae and Lauraceae (Bosque et al. 1995, Snow 1979, Snow 1962a). In the above-mentioned studies, investigators determined the diet of the Oilbird by identifying the regurgitated seeds found in or near caves where the species roosts. It seems likely that the Aguaruna also learn about the Oilbird's diet in a similar way. On one occasion, when we traveled to Oilbird caves near the study sites, our Aguaruna guides identified the seeds present below the opening of the cave. Aguaruna informants in the present study listed fruits from the families Arecaceae, Burseraceae and Lauraceae as the primary food sources for the Oilbird.

In Table 3, we compare diet information from Aguaruna informants to diet data collected by Snow (1979) in Ecuador in the eastern Andean foothills at $550 \mathrm{~m}$ a.s.I. in an area near our own study sites. All families mentioned by the Aguaruna are also reported in Snow's data. Snow also lists two other families, that the Aguaruna did not mention, Annonaceae and Polygonaceae, but these families account for only $4 \%$ and $2 \%$ respectively of the randomly collected samples of seeds.

\section{Ramphastidae: Toucans}

Toucans are distinctive birds known for their spectacular bills. Aguaruna folk genera for this family include the toucanets ikáuk (Aulacorhynchus sp.) and kajúntsam (Selenidera reinwardtii); the araçari pinínch (Pteroglossus sp.); and the toucans kéjua ( $R$. vitellinus), piígsha (Ramphastos cuvieri) and sháatak, which our informants identify as Ramphastos ambiguus and Guallart (1969) reports as Andigena hypoglauca. The word tsukagká is a more general term to refer to species in the genus Ramphastos. The Aguaruna regard all birds in this group to be related as kumpají. The Ramphastidae may be consumed and are especially valued for their bright feathers, which are used to decorate the tawás, a crown worn by men.

Toucans and araçaris are mainly frugivorous birds that forage in the canopy, and play an important role in seed dispersal; they are also known to supplement their diet with arthropods and the eggs and nestlings of other birds. The Aguaruna consider the members of this family to feed primarily on fruit; informants did not list any animal food sources for species in this family. All toucans were considered as canopy dwelling. Aguaruna informants listed many tree species as food sources for toucans; the most commonly mentioned families were Annonaceae, Araliaceae (genus Schefflera), Arecaceae (genus Jessenia), Burseraceae (genus Dacryodes), Flacourtiaceae (genus Carpotroche), Lauraceae, Melastomataceae, Meliaceae (genus Guarea), Moraceae (genus Pseudolmedia), Myristicaceae, Rubiaceae (genus Isertia) and Sapindaceae (genus Allophylus).

The Channel-billed Toucan ( $R$. vitellinus) ranges from Colombia and Venezuela in the north to Bolivia in the south, and Brazil in the east. The species is common in lowland and gallery forest and is found up to $1700 \mathrm{~m}$ a.s.l. Galetti et al. (2000) published diet data for the Channel-billed Toucan based on observations in lowland Brazilian Atlantic forest while Holbrook (n.d.) has reported diet data for this species in humid lowland forest in eastern Ecuador. Ten of the twelve $(83 \%)$ of botanical families that Aguaruna informants mentioned for this species also appear in one or both of the above-mentioned studies (Table 4). 
Table 3. Diet data for Táyu (Oilbird Steatornis caripensis)

\begin{tabular}{|c|c|c|}
\hline \multirow{2}{*}{$\begin{array}{l}\text { ORNITHOLOGICAL DATA }{ }^{1} \\
\text { (SCIENTIFIC NAME) }\end{array}$} & \multicolumn{2}{|c|}{ AGUARUNA DATA } \\
\hline & SCIENTIFIC NAME & AGUARUNA NAME \\
\hline \multicolumn{3}{|l|}{ Arecaceae } \\
\hline Jessenia bataua (Mart.) Burret & unidentified species ${ }^{2}$ & kugkúk \\
\hline Euterpe sp. & Euterpe precatoria Mart. $^{2}$ & sáke \\
\hline- & Oenocarpus mapora ${ }^{3}$ & shímpi \\
\hline \multicolumn{3}{|l|}{ Burseraceae } \\
\hline Dacryodes sp. & Dacryodes kukachkana L.O. Williams & múun kunchái \\
\hline$\longrightarrow$ & Dacryodes peruviana (Loes.) H.J. Lam & númi kunchái \\
\hline$\longrightarrow$ & Dacryodes nitens & tsáju kunchái \\
\hline- & Dacryodes sp. & újuts \\
\hline \multicolumn{3}{|l|}{ Lauraceae } \\
\hline Aniba sp. and other unidentified species & Nectandra cuneatocordata Mez & mantagá \\
\hline$\longrightarrow$ & $\begin{array}{l}\text { Ocotea argyrophylla } \\
\text { Ocotea longifolia }\end{array}$ & tuntúu tínchi \\
\hline \multicolumn{3}{|l|}{ Annonaceae } \\
\hline an unidentified species & $\longrightarrow$ & $\longrightarrow$ \\
\hline \multicolumn{3}{|l|}{ Polygonaceae } \\
\hline Coccoloba sp. & $\longrightarrow$ & $\longrightarrow$ \\
\hline
\end{tabular}

${ }^{1}$ Snow 1979

${ }^{2}$ from ethnobotanical collections of Berlin et al. n.d.

${ }^{3}$ from ethnobotanical collections of Guallart 1997

\section{Pipridae: Manakins}

The Aguaruna appear to have a covert category that corresponds fairly well to the family Pipridae (manakins). Informants typically group together the following birds as companions: achayáp ( $P$. erythrocephala), chiájmach (Pipra filicauda), shitagkuí (Pipra coronata), pinchínam (Machaeropterus regulus) and apú wishám (Chloropipo holochlora). Informants typically distinguished females of these species at close range, but at a distance tended to apply the name wishám to the females of several manakin species. Informants disagreed as to whether tashíjim (Manacus manacus) should be placed with the others. Some informants included birds from other families in this group, particularly jínincham (Mionectes oleagineus). The Ochre-bellied Flycatcher ( $M$. oleagineus) shares some important characteristics with manakins including a diet high in fruits and berries, and lekking behaviour; it is often associated with manakin feeding flocks, so it can be considered quite literally a 'companion' of the manakins (Westcott \& Smith 1994). The Aguaruna report that birds in this group forage mainly on Melastomataceae but also on Flacourtiaceae (genus Carpotroche), Myristicaceae and Rubiaceae (genus Psychotria). Some infor- mants also mentioned that birds in this group can eat insects.

The Golden-headed Manakin ( $P$. erythrocephala) is found from Panama and Trinidad, in the north, to northern Peru in the south, and Brazil and the Guianas in the East. It is common in lowland primary and secondary forest and eats mainly berries and insects. Snow (1962b) made 445 records of 43 plants foraged on by the Golden-headed Manakin in Trinidad over the course of several years. In Table 5, we compare the plants most often mentioned by Aguaruna informants to Snow's extensive data on this species. In the interest of brevity, we have only listed Snow's data to the level of genus. Considering the wide geographical separation between his study location and our own, one would not expect to find the same plant species present in both locations. Four out of five (80\%) of the botanical families mentioned by Aguaruna informants also appear in Snow (1962b) (Table 5). Snow mentions 14 additional families that Aguaruna informants did not name. It is worth noting that $63 \%$ of Snow's records were from the family Melastomataceae, far greater than any of the other families he mentioned, while Aguaruna informants also reported plants in the Melastomataceae much more commonly than plants in other families. 


\section{Jernigan \& Dauphiné - Aguaruna Knowledge of Bird Foraging Ecology: A comparison with scientific data}

Table 4. Diet data for Kéjua (Channel-billed Toucan Ramphastos vitellinus)

\begin{tabular}{|c|c|c|}
\hline \multirow{2}{*}{$\begin{array}{l}\text { ORNITHOLOGICAL DATA } \\
\text { (SCIENTIFIC NAME) }\end{array}$} & \multicolumn{2}{|l|}{ AGUARUNA DATA } \\
\hline & SCIENTIFIC NAME & AGUARUNA NAME \\
\hline \multicolumn{3}{|l|}{ Annonaceae } \\
\hline Rollinia pittieri Saff. ${ }^{1}$ & Pseudoxandra sp. & yaisá kumpají \\
\hline \multicolumn{3}{|l|}{ Araliaceae } \\
\hline $\begin{array}{l}\text { Dendropanax sp. }{ }^{2} \\
\text { Schefflera morototoni (Aubl.) Magu- } \\
\text { ire, Steyerm. \& Frodin }{ }^{1}\end{array}$ & Schefflera sp. ${ }^{3}$ & séntuch \\
\hline \multicolumn{3}{|l|}{ Arecaceae } \\
\hline Euterpe edulis Mart. $^{2}$ & unidentified species ${ }^{3}$ & kugkúk \\
\hline \multicolumn{3}{|l|}{ Burseraceae } \\
\hline Protium widgrenii Engl. ${ }^{2}$ & Dacryodes kukachkana & múun kunchái \\
\hline$\longrightarrow$ & Dacryodes sp. & újuts \\
\hline \multicolumn{3}{|l|}{ Caricaceae } \\
\hline- & Carica sp. & shiwanúk \\
\hline \multicolumn{3}{|l|}{ Euphorbiaceae } \\
\hline $\begin{array}{l}\text { Hyeronima alchorneoides Allemão² } \\
\text { Margaritaria nobilis L.f. }\end{array}$ & - & - \\
\hline \multicolumn{3}{|l|}{ Lauraceae } \\
\hline undetermined species ${ }^{2}$ & $\begin{array}{l}\text { Ocotea floribunda } \\
\text { Ocotea wachenheimir }\end{array}$ & batút \\
\hline undetermined species ${ }^{1}$ & $\begin{array}{l}\text { Licaria sp. } \\
\text { Ocotea costulata }\end{array}$ & káikua \\
\hline Ocotea sp. $1^{1}$ & Nectandra cuneatocordata & mantagá \\
\hline Ocotea sp. $2^{1}$ & various Lauraceae & tínchi \\
\hline Rhodostemonodaphne sp. ${ }^{1}$ & cf. Nectandra schomburgkii Meisn. & wampúsnum \\
\hline \multicolumn{3}{|l|}{ Melastomataceae } \\
\hline$\longrightarrow$ & $\begin{array}{l}\text { Miconia bulbalina Naudin } \\
\text { Miconia serrulata (DC.) Naudin }\end{array}$ & chijáwe \\
\hline$\longrightarrow$ & Miconia poeppigii ${ }^{3}$ & yujúya \\
\hline \multicolumn{3}{|l|}{ Meliaceae } \\
\hline 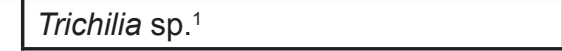 & Guarea sp. & cedrón \\
\hline$\longrightarrow$ & Guarea macrophylla subsp. macrophylla Vahl & ishpíg \\
\hline- & $\begin{array}{l}\text { Guarea pubescens subsp. pubescens (Rich.) A. } \\
\text { Juss. }^{3}\end{array}$ & kúwai \\
\hline \multicolumn{3}{|l|}{ Moraceae } \\
\hline Ficus sp. $^{1}$ & Ficus sp. & yapít \\
\hline \multicolumn{3}{|l|}{ Myristicaceae } \\
\hline Virola gardneri (A. DC.) Warb. ${ }^{2}$ & $\begin{array}{l}\text { Iryanthera tricornis Ducke } \\
\text { Virola pavonis (A. DC.) A.C. Sm. }\end{array}$ & ejésh \\
\hline Virola oleifera (Schott) A.C. Sm. ${ }^{2}$ & Virola sp. & takáikit tsémpu \\
\hline $\begin{array}{l}\text { Virola flexuosa A.C. Sm. }{ }^{1} \\
\text { V. elongata }{ }^{1}\end{array}$ & $\begin{array}{l}\text { Iryanthera juruensis Warb. } \\
\text { Virola elongata (Benth.) Warb. }\end{array}$ & úntuch tsémpu \\
\hline
\end{tabular}




\begin{tabular}{|c|c|c|}
\hline \multirow{2}{*}{$\begin{array}{l}\text { ORNITHOLOGICAL DATA } \\
\text { (SCIENTIFIC NAME) }\end{array}$} & \multicolumn{2}{|c|}{ AGUARUNA DATA } \\
\hline & SCIENTIFIC NAME & AGUARUNA NAME \\
\hline \multicolumn{3}{|l|}{ Myrtaceae } \\
\hline undetermined species ${ }^{2}$ & $\longrightarrow$ & $\longrightarrow$ \\
\hline \multicolumn{3}{|l|}{ Phytolaccaceae } \\
\hline Phytolacca dioica L. ${ }^{2}$ & $\longrightarrow$ & 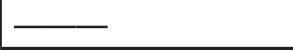 \\
\hline \multicolumn{3}{|l|}{ Rubiaceae } \\
\hline Psychotria mapourioides $\mathrm{DC}{ }^{2}$ & Isertia laevis (Triana) B.M. Boom & tsáagnum \\
\hline \multicolumn{3}{|l|}{ Sapindaceae } \\
\hline Matayba elaeagnoides Radlk. ${ }^{2}$ & $\begin{array}{l}\text { Allophylus divaricatus Radlk. } \\
\text { Allophylus floribundus (Poepp.) Radlk. }\end{array}$ & jimájima \\
\hline \multicolumn{3}{|l|}{ Sapotaceae } \\
\hline Chrysophyllum flexuosum Mart. ${ }^{2}$ & $\longrightarrow$ & 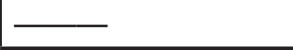 \\
\hline \multicolumn{3}{|l|}{ Urticaceae } \\
\hline Cecropia sp. $^{1}$ & - & chími \\
\hline Cecropia sp. $^{2}$ & - & yapít \\
\hline \multicolumn{3}{|l|}{ Verbenaceae } \\
\hline Citharexylum myrianthum Cham. $^{2}$ & - & - \\
\hline
\end{tabular}

${ }^{1}$ Holbrook n.d.

2 Galetti et al. 2000

${ }^{3}$ from ethnobotanical collections of Berlin et al. n.d.

\section{Conclusion}

At the level of plant families, Aguaruna knowledge exhibits a high level of correspondence to evidence from ornithological studies, particularly those studies conducted in locations closest to our own study site in terms of both distance and ecological similarity. Snow's (1979) study of Oilbird ecology was the most similar to our study area in terms of geographical distance and elevation. There is a high level of agreement between data sets at the level of plant family. The three plant families mentioned by Aguaruna informants, Arecaceae, Burseraceae and Lauraceae also accounted for $96 \%$ of the seeds that Snow recorded in a random sample. There was also a reasonably high agreement for the Channel-billed Toucan. For this species, we compared Aguaruna knowledge with two ornithological studies, one of which was conducted in the lowland Ecuadorian Amazon (Holbrook n.d.), and the other in the Brazilian Atlantic forest (Galetti et al. 2000). For this species, $83 \%$ of the plant families mentioned by Aguaruna informants also appeared in one or both of the above-mentioned studies. In the case of the Golden-headed Manakin, $80 \%$ of the plant families that Aguaruna informants mentioned also appear in Snow's (1962b) study of this species in Trinidad. Both the Aguaruna and Snow indicate the primary importance of fruits of the Melastomataceae for the Golden-headed Manakin. However, Snow lists many plant families that the Aguaruna did not mention. The fact that Snow's study was a highly detailed one involving 445 ob- servations over several years might account for this difference. The geographical separation between Trinidad and the Peruvian Amazon may also be a factor. Sixty-seven percent of plant families that the Aguaruna mention for the Blue-headed Parrot also appear in Collar (1997).

The least agreement between Aguaruna knowledge and scientific evidence was found in the case of the Wattled Guan. Only $40 \%$ of plant families mentioned by the Aguaruna were reported by Ríos et al. (2005). Ríos et al. conducted their study at an elevation of $1800-2100 \mathrm{~m}$ a.s.I. which is significantly higher than our study sites at $290 \mathrm{~m}$ and $400 \mathrm{~m}$ a.s.I. respectively, and they only listed a few of the most common food sources they observed. In this case, limited agreement between data sets may be due to the geographical and elevation differences in the sites of each study.

We present LEK research of this kind in order to contribute to the larger goal of promoting dialogue between indigenous and scientific systems of knowledge. Some social scientists (e.g., Agrawal 2002, Nadasdy 2003) have been critical of efforts to combine scientific and indigenous knowledge in conservation and development projects, arguing that efforts of this kind often mainly benefit parties other than the indigenous peoples in question. Murray (2000) points out resistance to the use of indigenous knowledge on the part of biologists, in part because indigenous LEK and scientific knowledge do not always map on to each 


\section{Jernigan \& Dauphiné - Aguaruna Knowledge of Bird Foraging Ecology: A comparison with scientific data}

Table 5. Diet Data for Achayáp (Golden-headed Manakin Pipra erythrocephala)

\begin{tabular}{|c|c|c|}
\hline \multirow{2}{*}{$\begin{array}{l}\text { ORNITHOLOGICAL DATA }{ }^{1} \\
\text { (SCIENTIFIC NAME) }\end{array}$} & \multicolumn{2}{|c|}{ AGUARUNA DATA } \\
\hline & SCIENTIFIC NAME & AGUARUNA NAME \\
\hline \multicolumn{3}{|l|}{ Aquifoliaceae } \\
\hline Ilex sp. & - & - \\
\hline \multicolumn{3}{|l|}{ Araliaceae } \\
\hline Schefflera sp. & - & - \\
\hline \multicolumn{3}{|l|}{ Asteraceae } \\
\hline Wulffia sp. & $\longrightarrow$ & $\longrightarrow$ \\
\hline \multicolumn{3}{|l|}{ Burseraceae } \\
\hline Protium sp. & $\longrightarrow$ & $\longrightarrow$ \\
\hline \multicolumn{3}{|l|}{ Dilleniaceae } \\
\hline $\begin{array}{l}\text { Davilla sp. } \\
\text { Doliocarpus sp. } \\
\text { Pinzona sp. }\end{array}$ & $\longrightarrow$ & $\longrightarrow$ \\
\hline \multicolumn{3}{|l|}{ Elaeocarpaceae } \\
\hline Sloanea sp. & - & - \\
\hline \multicolumn{3}{|l|}{ Euphorbiaceae } \\
\hline $\begin{array}{l}\text { Alchornea sp. } \\
\text { Hieronyma sp. } \\
\text { Maprounea sp. } \\
\text { Sapium sp. }\end{array}$ & $\begin{array}{l}\text { Alchornea glandulosa Poepp. } \\
\text { Conceveiba rhytidocarpa Müll. Arg. }{ }^{2}\end{array}$ & kántsa \\
\hline \multicolumn{3}{|l|}{ Flacourtiaceae } \\
\hline Laetia sp. & Casearia arborea (Rich.) Urb. ${ }^{2}$ & umpákainim \\
\hline \multicolumn{3}{|l|}{ Lauraceae } \\
\hline $\begin{array}{l}\text { Ocotea sp. } \\
\text { Phoebe sp. }\end{array}$ & - & - \\
\hline \multicolumn{3}{|l|}{ Melastomataceae } \\
\hline Henriettea sp. & Miconia sp. & antumú chinchák \\
\hline Miconia sp. & $\begin{array}{l}\text { Miconia bulbalina } \\
\text { Miconia serrulata }\end{array}$ & chijáwe \\
\hline- & various species in Melastomataceae & chinchák \\
\hline$\longrightarrow$ & $\begin{array}{l}\text { Miconia affinis DC. } \\
\text { Miconia sp. }\end{array}$ & kapantú chinchák \\
\hline- & Bellucia cf. pentamera Naudin & sáu chinchák \\
\hline- & Miconia ternatifolia Triana & tseék \\
\hline$\longrightarrow$ & Miconia poeppigii ${ }^{2}$ & yujúya \\
\hline \multicolumn{3}{|l|}{ Moraceae } \\
\hline Ficus sp. & - & - \\
\hline \multicolumn{3}{|l|}{ Myristicaceae } \\
\hline - & Virola sp. & takáikit tsémpu \\
\hline \multicolumn{3}{|l|}{ Myrtaceae } \\
\hline Myrcia sp. & $\longrightarrow$ & $\longrightarrow$ \\
\hline \multicolumn{3}{|l|}{ Nyctaginaceae } \\
\hline Pisonia sp. & - & - \\
\hline
\end{tabular}




\begin{tabular}{|c|c|c|}
\hline \multirow{2}{*}{$\begin{array}{l}\text { ORNITHOLOGICAL DATA }{ }^{1} \\
\text { (SCIENTIFIC NAME) }\end{array}$} & \multicolumn{2}{|c|}{ AGUARUNA DATA } \\
\hline & SCIENTIFIC NAME & AGUARUNA NAME \\
\hline \multicolumn{3}{|l|}{ Rubiaceae } \\
\hline $\begin{array}{l}\text { Cephaelis sp. } \\
\text { Isertia sp. } \\
\text { Malanea sp. } \\
\text { Palicourea sp. } \\
\text { Psychotria sp. }\end{array}$ & Psychotria sp. & mujayá shuípiu \\
\hline \multicolumn{3}{|l|}{ Phytolaccaceae } \\
\hline Phytolacca sp. & - & - \\
\hline \multicolumn{3}{|l|}{ Solanaceae } \\
\hline Cestrum sp. & - & - \\
\hline \multicolumn{3}{|l|}{ Urticaceae } \\
\hline Trema sp. & - & - \\
\hline \multicolumn{3}{|l|}{ Verbenaceae } \\
\hline Aegiphila sp. & - & - \\
\hline
\end{tabular}

${ }^{1}$ Snow 1962

${ }^{2}$ from ethnobotanical collections of Berlin et al. n.d.

other neatly, particularly where questions of value are concerned. Other authors have argued that practical benefits can emerge from this kind of collaboration. Posey \& Camargo (2002:133), for example, have maintained that: "It is precisely this type of integrated knowledge, based upon intricacies of indigenous science, that offers many new ideas for those persons and institutions interested in long-term, ecologically and socially sound plans for development and conservation in the humid tropics." The upper Marañón region is considered a high priority area for both bird and plant conservation, based on species diversity and endemism, and yet it remains little-known by scientists (Rodriguez \& Young 2000). We believe that Aguaruna LEK can help advance science in this region where little scientific study has taken place.

\section{Acknowledgements}

Funding for this project was made possible through grants from the National Science Foundation, the Critically Endangered Neotropical Species Fund at Conservation International, the IDEAS program at the University of Georgia, the Georgia Ornithological Society, the Tinker and Wenner-Gren Foundations. We thank the Comunidades Nativas de Wawas-Anexo Wichim and Kayamas for inviting and hosting fieldwork and the Instituto Nacional de Recursos Naturales (INRENA) for granting permission to conduct research. For field and logistical support, we are grateful to Martha and Oscar Tsamajain Shiwig, Roberto Jeremías Wampush, Enrique Tsamajain Chumpi, Agustín and Segundo Tsamajain Yagkuag, Anika Mahoney, Juan Díaz Alvan, José Alvarez Alonso, José Lirio, and Daniel M. Brooks. KJ extends special appreciation to Brent Ber- lin, Elois Ann Berlin, Steve Kowaleski, Glenn Shepard, the Universidad Nacional Mayor de San Marcos, Kelsey Hannon, Kintamai Agkuash Anag, Emiliano Nugkum, Jorge Shinkip and Martin, Nestor, and Gregorio Réategui. ND wishes to express heartfelt gratitude to Oscar Beingolea, Miguel and Wilfredo Aguilar Torres, Flor Idiáquez Acevedo, Flor and Jaso Angulo, and Yolanda Rojas for their generous hospitality during her extended stays in Peru, to Robert J. Cooper for his help and guidance, and to the Warnell School of Forestry and Natural Resources at the University of Georgia for financial support.

\section{Literature Cited}

Agrawal, A. 2002. Indigenous knowledges and the politics of classification. International Social Science Journal 54(173):287-297.

Berlin, B. 1970. A Preliminary Ethnobotanical Survey of the Aguaruna Region of the Upper Marañón River Valley, Amazonas, Peru. Report to the Wenner-Gren Foundation for Anthropological Research, Washington, D.C.

Berlin, B. 1992. Ethnobiological Classification: Principles of Categorization of Plants and Animals in Traditional Societies. Princeton University Press, Oxford.

Berlin, B. \& E.A. Berlin. 1983. Adaptation and Ethnozoological Classification: Theoretical implications of animal resources and diet of the Aguaruna and Huambisa. Pp 301-325 in Adaptative Responses of Native Amazonians (Studies in Anthropology). Edited by Hames, R.B. \& Vickers W.T. Academic Press, New York. 


\section{Jernigan \& Dauphiné - Aguaruna Knowledge of Bird Foraging Ecology: A comparison with scientific data}

Berlin, B., J.S. Boster \& J.P. O'Neil. 1981. The perceptual bases of ethnobiological classification: Evidence from Aguaruna Jívaro ornithology. Journal of Ethnobiology 1:95-108.

Berlin, B. \& J.P. O'Neill. n.d. Field notes, Cordillera del Condor, Peru. Unpublished.

Berlin, B., C.M. Crandall \& W.H. Lewis. n.d. Taxonomic Checklist of Plants Collected in the Department of Amazonas, Peru, 1972-1980. Unpublished.

Bosque C., R. Ramirez \& D. Rodriguez. 1995. The diet of the oilbird in Venezuela. Ornitología Neotropical 6:67-80.

Boster, J., B. Berlin \& J.P. O'Neil. 1986. The correspondence of Jivaroan to scientific ornithology. American Anthropologist 88:569-583.

Brooks, D.M. 2006. Conserving Cracids: The most threatened family of birds in the Americas. Miscellaneous Publications of the Houston Museum of Natural Science 6.

Brown, M.F. 1984. Una Paz Incierta: Historia y cultura de las Comunidades Aguarunas Frente al Impacto de la Carretera Marginal. Centro Amazónico de Antropología y Aplicación Práctica, Lima, Peru.

Clements, J.F. \& N. Shany. 2001. A Field Guide to the Birds of Peru. Ibis Publishing Company, Temecula, CA.

Collar, N. 1997. Family Psittacidae (Parrots). Pp 280-477 in Handbook of the Birds of the World. Vol. 4: Sandgrouse to Cuckoos. Edited by J. del Hoyo, A. Elliot \& J. Sargatal. Lynx Edicions, Barcelona.

Dauphiné, N., A. Tsamajain Yagkuag \& R.J. Cooper. In press. Bird conservation in Aguaruna-Jívaro communities in the Cordillera de Colán, Peru. Ornitología Neotropical 19.

del Hoyo, J. 1994. Family Cracidae (Chachalacas, Guans and Curassows). Pp 310-363 in Handbook of the Birds of the World. Vol. 2: New World Vultures to Guineafowl. Edited by J. del Hoyo, A. Elliot \& J. Sargatal. Lynx Edicions, Barcelona.

Fleck, D.W. \& J.D. Harder. 2000. Matsés Indian rainforest habitat classification and mammalian diversity in Amazonian Peru. Journal of Ethnobiology 20:1-36.

Galetti, M., R. Laps \& M.A. Pizo. 2000. Frugivory by toucans (Ramphastidae) at two altitudes in the Atlantic Forest of Brazil. Biotropica 32:842-850.

Gilchrist, G., M. Mallory \& F. Merkel. 2005. Can local ecological knowledge contribute to wildlife management?
Case studies of migratory birds. Ecology and Society 10(1):20. www.ecologyandsociety.org/vol10/iss1/art20.

Gilchrist, G., \& M.L. Mallory. 2007. Comparing expertbased science with local ecological knowledge: What are we afraid of? Ecology and Society 12(1):r1. www.ecologyandsociety.org/vol12/iss1/resp1.

Gilmore, M. 2005. Maijuna rain forest habitat classification in the Peruvian Amazon. Paper presented at the 46th Annual Meeting of the Society for Economic Botany, Ft. Worth, Texas.

Guallart, J.M. 1969. Nomenclatura Jíbara-Aguaruna de especies de aves en el Alto Marañón. Mesa Redonda de Ciencias Prehistóricas y Antropólogas 1:150-160.

Guallart, J.M. 1997. La Tierra de los Cinco Ríos. Instituto Riva-Agüero, Lima, Perú.

Hilty, S. \& W. Brown. 1986. A Guide to the Birds of Colombia. Princeton University Press, Princeton, NJ.

Holbrook, K.M. n.d. Seed Dispersal by Toucans in Amazonia, Ecuador. Unpublished Field Report.

IUCN. 2006. 2006 IUCN RedList of Threatened Species. www.iucnredlist.org

Jernigan, K. 2006. An Ethnobiological Exploration of Sensory and Ecological Aspects of Tree Identification among the Aguaruna Jivaro. Ph.D. Dissertation. University of Georgia, Athens, Georgia.

Lewis, W.H., G. Lamas, A. Vaisberg, D.G. Corley \& C. Sarasara. 1999. Peruvian medicinal plant sources of new pharmaceuticals. Pharmaceutical Biology 37(Supp 1):6983.

Murray, D. 2000. Tempered Optimism:Recognizing the Barriers to the Use of Traditional Ecological Knowledge in Arctic Canada. Master's Thesis. Carleton University, Canada.

Nabhan, G.P. 2000. Interspecific relationships affecting endangered species recognized by O'odham and Comcaac cultures. 10:1288-1295.

Nadasdy, P. 2003. Hunters and Bureaucrats: Power, Knowledge, and Aboriginal-state Relations in the Southwest Yukon. UBC Press, Vancouver, British Columbia.

Parker, T.A. III., D.F. Stotz \& J.F. Fitzpatrick. 1996. Ecological and distributional databases. Pp 113-436 in Neotropical Birds: Ecology and Conservation. Edited by D.F. Stotz, J.W. Fitzpatrick, T.A. Parker, III, \& D.K. Moskovits. University of Chicago Press, Chicago, IL. 
Posey, D. 1979. Ethnoentomology of the Gorotire Kayapó of Central Brazil. Ph.D. Dissertation. University of Georgia, Athens, Georgia.

Posey, D. 1981. Wasps, warriors and fearless men: Ethnoentomology of the Kayapó Indians of Central Brazil. Journal of Ethnobiology 1:165-174.

Posey, D. \& J.M.F. Camargo. 2002. Additional notes on the classification and knowledge of stingless bees (Meliponinae, Apidae, Hymenoptera) by Kayapó Indians of Gorotire, Pará, Brazil. Pp 112-133 in Kayapo Ethnoecology and Culture. Edited by K. Plenderleith. Routledge, New York, NY.

Ridgely, R.S. \& P.J. Greenfield. 2001. The Birds of Ecuador Field Guide. Cornell University Press, Ithaca, NY.

Ríos, M.M., G.A. Londoño \& M.C. Muñoz. 2005. Density and ecology of the Wattled Guan (Aburria aburri) in an Andean forest. Bulletin of the Cracid Specialist Group 21: 33-37.

Roca, R.L. 1994. Oilbirds of Venezuela: Ecology and Conservation. Nuttall Ornithological Club Publication No. 24, Cambridge, Massachusetts.

Rodriguez, L.O. \& K.R. Young. 2000. Biological diversity of Peru: Determining priority areas for conservation. Ambio 29:329-337.
Serra, G. 2003. The discovery of Northern Bald Ibises in Syria. World Birdwatch 25(1):10-13.

Shepard, G.H., D.W. Yu, M. Lizarralde \& M. Italiano. 2001. Rain forest habitat classification among the Matsigenka of the Peruvian Amazon. Journal of Ethnobiology 21:1-38.

Sick, H. 1993. Birds in Brazil: A Natural History. Princeton University Press, Princeton, NJ.

Snow, B.K. 1979. The Oilbirds of Los Tayos. Wilson Bulletin $91: 457-461$.

Snow, D.W. 1962a. The natural history of the Oilbird (Steatornis caripensis) in Trinidad, W.I. Part 2: Population, breeding ecology, and food. Zoologica 47:199-221.

Snow D.W. 1962b. A field study of the Golden-headed Manakin, Pipra erythrocephala, in Trinidad, W.I. Zoologica 47:183-198.

Thomas, B.T. 1999. Family Steatornithidae (Oilbird). Pp 244-251 in Handbook of the Birds of the World. Vol. 5: Barn-owls to Hummingbirds. Edited by J. del Hoyo, J., A. Elliot \& J. Sargatal. Lynx Edicions, Barcelona.

Westcott, D.A. \& J.N.M. Smith. 1994. Behavior and social organization during the breeding season in Mionectes oleagineus, a lekking flycatcher. The Condor 96:672-683. 